Hence, to again tax these houses a second time by taxing their private enclosed gardens would be unjustifiable. It comes to this, that it has been suggested to put an additional tax on picturesque town-planning, tree-planting, hedges, grass lawns, shrubs and flowers, because these embellishments have been provided by private enterprise.

If the taxation of private garden enclosures were granted, then would it not follow that the taxation of houses bordering upon lakes, rivers, and the sea, would also be retaxed, because of their adjoining aquatic air spaces? Such taxes on air spaces would be even more injurious to public health than the old tax on windows which were guilty of admitting sunlight, warmth, and air.

To a void noise and vibrations created by " tubes," trams, trains, traffic, and motor-cars, I have long resided in a secluded, sheltered "square" in Brighton, which, in addition to extensive elegant enclosed private gardens and sea terraces sloping down to the beach below, has a unique financial history that has hitherto escaped publicity.

These Sussex Square Gardens, constituting the Kemp Town Enclosures, are a model miniature marine garden city, being Brighton's chiefest adornment.

Early in the nineteenth century Thomas Read Kemp (1781 to 1844) converted his Black Rock Farm and adjacent property into a magnificent estate, named, after him, Kemp Town, the attraction and adornment of which are the enclosed picturesque "Sussex Square" Gardens, covering some ten acres, with their sea-terraces and grass-covered slopes, extending to upwards of half a mile along the beach.

The Park was planned by Sir Joseph Paxton, including beneath the main road or sea front a tunnel connecting the gardens with the marine terraces below. Under the highway on each side of the tunnel is a cleverly concealed cottage-like a cave dwelling - its roof being underneath the public footpath above. The top of the "Square" is nearly 120 feet above the sea's level.

Sheltered from northerly winds by an ivy-clad wall some 35 feet high, the upper and lower marine terraces contain a dozen capacious arches, providing excellent shelter and summer houses. This domain is only accessible to the residents of the 103 houses constituting this enclosed estate, the quiet and privacy of which pleased the King in 1908 when staying at the Duke of Fife's residence at the corner of "Sussex Square."

By 1837 Kemp's magnificent town-planning punished him with a loss exceeding $£ 500,000$. He died in comparative poverty in Paris in 1844.

For nearly a century these enclosures have been and are maintained by subscriptions from 103 owners and occupiers of houses on the estate. Their residents have paid extra local rates and taxes for access to the grounds, which yield neither income nor financial profit.

Of course this site can never be developed for building purposes, and to treat and tax it as land withheld from the market with a view to increased rent, is absurd. Indeed, already upwards of $£ 40,000$ for wages and materials have been distributed for the upkeep of this park by the owners and occupiers of houses upon this estate, where empty uninhabited houses also pay annual subscriptions for the maintenance of the gardens.

J. Lawrence-Hamilton, M.R.C.S.

30 Sussex Square, Brighton.

\section{POPULAR CURES.}

DEAR SiR,-I have just read with interest the article apon some pcpular cures. Could you find space for the following case, which appears to me to be worth recording.

My gardener's brother-in-law was reported to be dangerously ill. He had pneumonia. I asked how he was one day, and was told that he had recovered, but that this was not due to his club doctor, who was no good. He was cured by the application of sheep's lungs to the soles of his feet; it was described to me how the countryside was scoured for the lungs. This, combined with a bottle of brandy a day, was the treatment that put to shame our profession. Now hear the proof of the efficacy of sheep's lungs. This case appears to have been single pneumoniathis in itself is worthy of note. You have probably ob. served that "double pneumonia and pleurisy" is the usual and correct thing. Fortunately for science this case was exceptional, and the pneumonia was confined to one side; and it was found that the lungs applied to the foot corresponding to the affected side rapidly became putrid and stinking, whereas those applied to the other foot remained fresh and sweet.

These things happened in Wales, the land of faith and enthusiasms. Yours truly,

Bromyard, Worcester.

Ashton BeCK.

\section{VENTILATION IN OPERATING THEATRES.}

Sir,-In Mr. Lockwood's interesting lecture on the methods of attaining asepsis in operation theatres he puts the cubic capacity of a theatre to hold twenty people, in addition to the patient, at 8,000 to 10,000 cubic feet, and recommends that the air should be changed at least six times in the hour. Now, the recognised amount of air which should be supplied to each person in the room per hour is $3,000 \mathrm{ft}$. For twenty-one persons, therefore, the total amount required per hour is $63,000 \mathrm{ft}$. Taking the lesser dimension of 8,000 cubic feet, the air would have to be changed nearly eight times per hour; and the larger dimension would require a change of over six times (6.30). The amount of 3,000 cubic feet per head per hour was computed by De Chaumont as the quantity necessary "so to dilute the carbonic acid gas expired by an adult male in repose that the excess of carbonic acid gas in the air over that in the fresh air supplied is maintained at two volumes per 10,000 ; that limit of perception of clcseness of smell" (W. N. Shaw, F.R.S., "Air Currents and the Laws of Ventilation"). And though more recent authorities have recommended a lower standard, Dr. Shaw, in the work quoted, maintains that there is sufficient physical ground for adhering to De Chaumont's figures.

It would seem, therefore, that an accurate mode of arriving at the amount of air necessary for the ventilation of a theatre (or, indeed, of any other room) is by calculating the amount on De Chaumont's method and arranging the apparatus accordingly, rather than by assuming a more or less empirical rule for changing the air so many times per hour.

Another important point raised by Mr. Lockwood is the quality and unit of resistance of the filtering material. It would be useful if some careful experiments could be made from which definite rules could be deduced giving the rate of flow of air through different thicknesses of filtering material.

I am, Sir, yours faithfully,

KeIth D. Young.

17 Southampton Street, Bloomsbury, London, W.C., October 22, 1909.

\section{MEDICAL FEES AND THE PUBLIC:}

To the Editor of The Hospital.

DEAR SIR,-I was somewhat surpised to learn from your article upon the above subject, that the "average general practitioner's" fees are 'higher than they should be." Twelve years ago I started practice in a London suburb 